\title{
E-BRIEF
}

September 15, 2016

\section{Carbon Copies: The Prospects for an Economy-wide Carbon Price in Canada}

\author{
by \\ Tracy Snoddon
}

- Canadian provinces are using different approaches to put a price on greenhouse gases. Some are introducing a carbon tax, others a cap-and-trade system.

- Provinces might choose over time to link their carbon pricing regimes or coordinate their carbon prices; but the single, economy-wide carbon price needed to achieve emissions reductions in Canada at the lowest possible cost would be difficult, if not impossible, to achieve with this decentralized, interprovincial approach.

- To improve Canada's prospects for achieving a single economy-wide carbon price and cost-effective emissions reductions, the federal government should introduce a national carbon price floor and a federal carbon tax to work alongside provincial carbon-pricing policies.

Canada's decentralized, interprovincial approach to carbon pricing is appealing. Provinces choose the carbon-pricing instrument, the level of climate ambition and how to recycle carbon-pricing revenues to suit their unique circumstances. But this approach has led to different carbon prices in different provinces, meaning that higher-cost emissions reductions are being undertaken when lower-cost abatement opportunities are available. ${ }^{1}$ To achieve emissions reductions at the lowest possible cost, a single economy-wide carbon price is required. Could a decentralized, interprovincial approach deliver on this objective?

Despite recent initiatives, provincial efforts so far have failed to achieve a single Canada-wide carbon price, and Canada is not on track to achieve its national emissions reduction target for

The author thanks Benjamin Dachis, anonymous reviewers, and members of the Energy Policy Council of the C.D. Howe Institute for comments on earlier drafts. She retains responsibility for any errors and the views expressed here.

1 In the global context, the existence of carbon price differentials across countries means that emissions reductions are not taking place in jurisdictions where they cost the least. 
2030. Differences in carbon pricing approach, climate policy stringency, energy sources, and economic drivers have proven difficult to overcome through provincial action alone.

This E-Brief accordingly recommends that the federal government:

- take an active role in carbon pricing with the aim of achieving a single economy-wide carbon price and improving the cost effectiveness of emissions reductions in Canada;

- implement a national carbon price floor and a federal carbon tax, to work alongside decentralized provincial policies to reduce - and eventually eliminate - carbon price differentials, to improve the prospects of Canada's achieving its 2030 emissions reduction target and to facilitate linking with other carbon-pricing systems in the longer term; and

- return to each province any federal carbon tax revenues collected.

\section{Making the Case for a Single Carbon Price}

A single price on carbon would ensure that the marginal cost of abatement - that is, the cost of an additional one tonne reduction in emissions - is equal across provinces. This, in turn, ensures that emissions reductions would occur where it is cheapest to do so. Ultimately, achieving a single carbon price worldwide is needed to achieve global emissions reductions at the lowest possible cost. Cost savings from a uniform carbon price are potentially substantial. The US cap-and-trade system, for sulphur dioxide $\left(\mathrm{SO}_{2}\right)$, for example, is estimated to have generated between US $\$ 0.7$ billion and US $\$ 2.1$ billion in abatement cost savings per year between 2000 and 2009 (Henry, Muller, and Mendelsohn 2011; Keohane 2006).

Carbon price differentials also have consequences for competitiveness, and can lead to emissions leakage, as emissions-generating activity moves from higher- to lower-carbon-price jurisdictions. A multimodel comparison exercise has found that, on average, 12 percent of the emissions reductions achieved from unilateral action were offset by increased emissions elsewhere (Böhringer, Balistreri, and Rutherford 2012). Although there is debate over their magnitude and importance, these issues are politically challenging, and can deter a province from pursing more ambitious climate policy in the decentralized, interprovincial setting, just as is the case in the international setting.

\section{Provincial Options for Reducing Carbon Price Differentials}

In a decentralized, interprovincial approach, provincial action would be needed to eliminate carbon price differentials. Provinces could link their carbon-pricing regimes formally or coordinate their carbon prices informally.

\section{Linking}

Provincial governments could establish institutional or other arrangements that allow different carbon-pricing regimes to interact. ${ }^{2}$ Direct, two-way linking between cap-and-trade regimes, for instance, means that each

2 Linking options are examined in Flachsland, Marschinski, and Edenhofer (2009); Haites and Mehling (2009); Haug, Frerk, and Santikarn (2015); Jaffe and Stavins (2007); and Ranson and Stavins (2015). 
partner would agree to recognize and accept the other partners' permits. Carbon prices and marginal abatement costs would be equalized as a result of unrestricted permit trading in the linked system's regional carbon market. Separate carbon-pricing regimes could also be linked indirectly by participating in a common third-party system, such as a common offset market (Cameron and McLeod 2015; Haug, Frerk and Santikarn 2015). Covered entities would be permitted to buy offsets - credits for verifiable emissions reductions generated outside the carbon-pricing regime - to satisfy some of their compliance obligations. If the offset price was lower than the going permit price, covered entities would demand offsets. This would put upward pressure on the offset price and downward pressure on permit prices, helping to reduce carbon-pricing differentials.

Finally, a carbon tax regime could be linked with a cap-and-trade system. Covered emitters in the carbon tax province could pay taxes in excess of their compliance requirements to earn emissions tax credits, and participants in either system could use permits and/or emissions tax credits to satisfy their compliance obligations. Free trade in permits and credits would eliminate pre-link differences in the permit price and carbon tax.

\section{Coordination}

Alternatively, provinces could decide to coordinate their carbon prices without allowing their carbon-pricing regimes to interact directly - that is, there would be no permit flows between provinces. Formal price coordination would require political cooperation, in the form of an interprovincial agreement or memorandum of understanding, to align carbon prices, and price increases, over time. Informal price coordination, in contrast, would not require explicit political cooperation, and could take many forms. For example, a province could set its carbon tax equal to the carbon price in another province, and determine under what conditions it would match any subsequent carbon price changes. Alternatively, a province could decide to set its carbon tax equal to a cap-and-trade province's reservation price for permits.

If linking and coordination efforts were successful, they could reduce differences in carbon prices and in the marginal cost of abatement across provinces, allowing provinces to achieve emission reductions at lower cost and, at the same time, alleviating competitiveness and leakage concerns.

\section{Current Linking and Coordination Efforts}

Some linking and coordination efforts are already underway. Quebec and California linked their cap-and-trade systems, establishing a regional carbon market with free trade in permits, in 2014 . And Ontario recently adopted a cap-and-trade program that it intends to link with the Quebec and California systems in 2018. The expansion of the regional carbon market is cause for optimism, since carbon price differentials between covered emitters in Ontario and Quebec will be eliminated. ${ }^{3}$ Recent modelling analysis finds that, compared to a stand-alone scheme, an Ontario cap-and-trade system linked to Quebec and California could achieve the province's 2020 emissionsreduction target with a lower carbon price, smaller loss of gross domestic product and less emissions leakage (Sawyer and Peters 2016).

3 Manitoba was also expected to pursue cap-and-trade, but the defeat of the New Democratic Party government in the recent provincial election makes this outcome less certain. 
Differences in design features, however, such as enforcement mechanisms or cost-containment measures, could compromise emissions reductions achieved in a linked system, and affect financial transfers between partners. As a consequence, harmonization is typically a political prerequisite for establishing a direct, two-way link between systems. Accordingly, major features of the Quebec and California cap-and-trade programs (and Ontario's newly created program) are harmonized (Purdon, Houle, and Lachapelle 2014).

Informal coordination efforts are also helping to reduce carbon price differentials. British Columbia adopted a broad-based carbon tax in 2008. Alberta only recently replaced its narrow carbon-pricing regime with a broadbased carbon price. The two systems are structurally different, but the provinces will have an identical carbon price of $\$ 30$ per tonne by 2018 . Moreover, both provinces have indicated their willingness to increase carbon prices if other jurisdictions do the same. Alberta's decision to harmonize its carbon price informally with that of British Columbia improves cost-effectiveness and addresses leakage and competitiveness concerns arising from the carbon price differential between the two provinces.

\section{Limitations of a Decentralized, Interprovincial Approach}

A number of obstacles stand in the way of eliminating carbon price differentials in a decentralized, interprovincial setting.

\section{Some Provinces Prefer Not to Link}

Both Alberta and British Columbia have revealed their preference for a stand-alone approach, with no provisions for out-of-province linkages, at least in the near term. Recent actions confirm this. British Columbia's proposal for its prospective liquefied natural gas (LNG) industry involves an emissions-intensity target for LNG facilities, within-province trading and the option to purchase BC-based emissions offsets. ${ }^{4}$ Alberta could have adopted a linked cap-and-trade program in 2015, but it chose instead to adopt a stand-alone carbon price. The decision not to link might reflect concerns about political autonomy and the financial flows associated with linking, or a desire to reap the co-benefits from in-province emissions reductions.

\section{Differences in Provincial Mitigation Efforts and Size Impede Linking}

Linking implies accepting new partners' emissions-reduction goals. Quebec and California have similar, but not identical, emissions-reduction targets (Table 1), demonstrating that linking need not require identical objectives. Adding Ontario to the Quebec-California system should not prove difficult, as the province has a similar emissions-reduction target, and has already harmonized key elements of its new cap-and-trade system.

Expanding links to include new partners, however, could be challenging, depending on their climate goals and size. ${ }^{5}$ Although Manitoba, for example, has a lower 2030 reduction target than does either Ontario or

4 Although some $21 \mathrm{LNG}$ proposals are under consideration, no project has yet reached the construction stage (Robins et al. 2016).

5 Evidence suggests that new partners that link to an existing cap-and-trade system usually are price takers with a small share of the combined post-link emissions cap. Linking is also more challenging when there are larger differences in pre-link carbon prices and in emissions reduction goals (Ranson and Stavins 2015). 


\section{Table 1: Carbon-Emissions Levels and Targets for 2020, Selected Jurisdictions}

\begin{tabular}{|c|c|c|c|c|}
\hline \multirow[t]{2}{*}{ Jurisdiction } & $\begin{array}{l}1990 \\
\text { Emissions }\end{array}$ & $\begin{array}{l}2014 \\
\text { Emissions }\end{array}$ & $\begin{array}{l}2020 \text { Target } \\
\text { Emissions }\end{array}$ & \multirow[t]{2}{*}{$\begin{array}{l}\text { Stated or Inferred Emissions- } \\
\text { Reduction Target, } 2020\end{array}$} \\
\hline & \multicolumn{3}{|c|}{ (megatonnes of $\mathrm{CO}_{2}$-equivalent emissions) } & \\
\hline California & 431 & 459 & 431 & $\begin{array}{l}\text { At } 1990 \text { levels } \\
(\approx 10 \% \text { below } 2005 \text { levels })\end{array}$ \\
\hline Quebec & 89 & 83 & 72 & $\begin{array}{l}20 \% \text { below } 1990 \text { levels } \\
(\approx 20 \% \text { below } 2005 \text { levels })\end{array}$ \\
\hline Ontario & 182 & 170 & 155 & 15\% below 1990 levels \\
\hline Manitoba & 19 & 21 & 17.6 & 6\% below 1990 levels \\
\hline British Columbia & 53 & 63 & 44 & $\begin{array}{l}33 \% \text { below } 2007 \text { levels } \\
(\approx 17 \% \text { below } 1990 \text { levels })\end{array}$ \\
\hline Alberta & 175 & 274 & 277 & $58 \%$ above 1990 levels \\
\hline \multicolumn{5}{|c|}{$\begin{array}{l}\text { Note: Manitoba does not have a } 2020 \text { target, but it did have a target of } 6 \text { percent below } 1990 \text { levels for 2012; the BC climate } \\
\text { plan states a target of } 33 \text { percent below } 2007 \text { levels, converted to a } 1990 \text { base. }\end{array}$} \\
\hline \multicolumn{5}{|c|}{$\begin{array}{l}\text { Sources: Provincial emissions data for } 1990 \text { and } 2014 \text { are from Canada (2016); emissions-reduction targets for } 2020 \text { were } \\
\text { obtained from the climate plans of the various jurisdictions. }\end{array}$} \\
\hline
\end{tabular}

Quebec, it would be a small partner, accounting for less than 3 percent of covered emissions in a linked QuebecCalifornia-Ontario system; ${ }^{6}$ as such, it would have a limited impact on the regional carbon market. Existing partners would be more likely to reject a province like Alberta, a large player with different climate goals. Adding Alberta to the linked cap and trade system would increase covered emissions significantly. The consequences for the permit price and the financial flows between partners may be undesirable from the existing partners' perspective. A large partner can also influence the regional carbon market through its choice of cap. It might be politically difficult for existing partners to accept a large partner with a more generous cap (and a less ambitious emissions-reduction goal) - under its new climate policy, Alberta's 2020 emissions are expected to be 58 percent higher than 1990 levels. Existing partners may also wish to avoid the permit price and financial flows effects that would result if Alberta joined the linked system and aligned its emissions-reduction target with that of either California or Quebec.

Emissions-reduction targets, expressed relative to a historical benchmark, admittedly are imperfect measures of stringency, as are metrics based on emissions intensity, explicit and implicit carbon prices or per capita abatement costs (Aldy, Pizer and Akimoto 2015). Moreover, disagreement over how to measure and compare mitigation efforts would interfere with the development of new provincial linkages and coordination efforts.

6 Manitoba aims to reduce emissions to 33 percent of 2005 levels (25.7 percent of 1990 levels) by 2030, compared with reductions to 37.5 percent and 37 percent of 1990 levels for Quebec and Ontario, respectively. 


\section{Hybrid Linking Is Unlikely}

It is possible to link different carbon-pricing instruments, such as a carbon tax and a cap-and-trade regime, but such links are unlikely to materialize. Linking British Columbia's $\$ 30$ per tonne carbon tax, for example, to the Quebec-California system, with a permit price of $\$ 17$ per tonne, would result in $\mathrm{BC}$ emitters demanding permits from the cap-and-trade system to cover their compliance obligations. In the absence of any restrictions on trading or compliance, carbon tax revenue would fall in British Columbia, perhaps dramatically. The decision to adopt a stand-alone carbon tax would signal an unwillingness to accept the financial flows (and budgetary implications) that would result from such a link. A province with a distinct preference for cap-and-trade also might be unwilling to accept a link that essentially converted cap-and-trade into a carbon tax (Metcalf and Weisbach 2012).

\section{No Mechanism Exists to Bring Reluctant Provinces on Board}

It has taken a decade to implement broad-based carbon pricing in four provinces. Extending formal coordination efforts and linkages to eliminate differentials across all provinces could take years to achieve, and might prove unattainable. The decentralized approach cannot force an unwilling province to adopt a carbonpricing regime or a specific carbon price. Interprovincial agreements are voluntary, and might not prove durable, as demonstrated in the United States by New Jersey's 2011 exit from the Regional Greenhouse Gas Initiative, a regional cap-and-trade program currently covering power sector emissions in nine states.

\section{National Objectives Are Difficult to Achieve}

Even if all provinces achieved their stated targets, emissions reductions would still fall short of Canada's national commitment to reduce total national emissions by 30 percent by 2030, relative to 2005 levels (Boothe and Boudreault 2016). The decentralized, interprovincial approach has no mechanism to ensure that provincial reduction efforts add up to the national commitment. The existence of different provincial carbon-pricing policies and prices also makes it more difficult for the federal government to develop a national carbon-pricing system that could be linked to other systems. The carbon-pricing provinces have implemented policies to deal with competitiveness and leakage issues, but this approach does not ensure a level playing field between the provinces or between Canada and its competitors, and makes the federal government's task of implementing economy-wide measures considerably more complex. ${ }^{7}$

\section{A Role for the Federal Government}

The decentralized, interprovincial approach to carbon pricing has considerable momentum, but if Canada wants to improve the cost effectiveness of its emissions reductions and achieve its 2030 emissions-reduction target, the federal government needs to get involved in carbon pricing.

7 The federal government also has more options for levelling the playing field, since it has the constitutional authority to implement border measures, if desired (Courchene and Allan 2008). 
Suppose the federal government were to set a carbon price floor, supported by a federal carbon tax that was adjusted to ensure emissions in each province faced at least the minimum price. ${ }^{\mathbf{1}}$ To implement such a proposal, the federal government would have to choose the initial price floor, the sectors of the economy covered by the carbon-pricing system, how to recycle revenues, how to measure provincial carbon prices and the price floor's path over time.

\section{The Initial Price Floor}

The initial price floor could be set equal to the highest provincial carbon price currently in effect. To illustrate, suppose the federal government were to set a $\$ 30$ per tonne price floor. If emissions in a province faced a price lower than this minimum, a federal tax would be applied to achieve an "all-in" carbon price of $\$ 30$. In a province with a carbon price of zero, the federal tax would be $\$ 30$ per tonne. In a cap-and-trade province such as Quebec, the tax would be adjusted downward to take into account the price paid for a one tonne permit currently around $\$ 17$. No federal tax would apply in British Columbia, since its carbon price already equals the price floor.

Alternatively, the initial price floor could be set equal to the lowest non-zero carbon price in effect - namely, the reservation price for permits in the Quebec-California system. In this case, emissions in a province with no carbon price would be subject to the federal carbon tax. The federal tax would not apply, however, in provinces with a carbon price at or above this level, save for areas of discrepancy in emissions coverage between the province and the federal tax.

\section{Emissions Coverage and Revenue Recycling}

Emissions coverage - that is, the tax base - should be as broad as possible and uniform across provinces. The expectation is that provinces would align their emissions coverage to match the federal government's definition of the tax base. Any federal carbon tax revenues derived from a province should be returned to it, ensuring that provinces retain control over the use of carbon-pricing revenues. Some provinces would be able to adjust their carbon price to match the price floor, so that no federal tax would be applied. But cap-and-trade provinces would have limited options to respond if the price floor exceeded the market price for permits. Responses such as lowering the cap or raising the reservation price for auctioned permits might jeopardize existing links with California. If adjustments were not possible, the federal tax should apply. Returning all federal revenues to the province could help compensate for these limitations.

\section{Measuring Provincial Carbon Prices}

Measuring provincial carbon prices is tricky, especially when some provinces participate in permit-trading schemes and others do not. Suppose the federal government were to set the floor at $\$ 30$ per tonne, while the permit price in Quebec remained at $\$ 17$. In the absence of permit trading with California, Quebec's carbon price would be higher. In that event, should the federal government impose a $\$ 13$ per tonne carbon tax (based on the permit price), or should Quebec's carbon price be adjusted upwards and a lower federal tax applied? New

8 This approach is similar to the United Kingdom's carbon price support rate, known as the Climate Change Levy (Sartor and Berghmans 2011). 
measures of carbon prices, adjusted for differences in emissions coverage and net imports of emissions permits, offer a potential solution to this problem (Beugin et al. 2016). ${ }^{\text {? }}$

\section{Adjusting the Federal Price Floor over Time}

Decisions on how to adjust the minimum price over time would depend on the initial price floor and on the importance attached to achieving Canada's 2030 emissions-reduction target. A high initial floor price would eliminate carbon price differentials immediately, improving the prospects for increasing the price floor over time and achieving the target. Starting with a lower price floor, in contrast, would recognize the cap-and-trade provinces' limited options for increasing carbon prices in the near term, and might be a more politically viable option. However, carbon price differentials would persist for longer and it is less likely that the 2030 target would be achieved.

\section{Evaluation}

A federal minimum carbon price, supported by a federal carbon tax, would have several advantages. It would ensure that emissions in all provinces, including those with a zero carbon price, were covered. It would improve the cost effectiveness of carbon pricing for the country as a whole, ensuring emission reductions occurred where they were least costly, and it would increase the likelihood of achieving the national emissions-reduction target for 2030. The federal initiative could be accompanied by complementary measures to help provinces adjust and to ensure an equitable sharing of the emissions-reduction burden. ${ }^{10}$ Finally, a federal minimum carbon price would improve Canada's ability to pursue linkages with other systems and, if desired, to implement economywide measures to address competitiveness and leakage issues. But there would also be political and economic challenges to overcome. Some, if not all, provinces would vigorously oppose such a proposal. Increasing the price floor over time to achieve the 2030 emissions-reduction target would entail economic costs, unevenly distributed across provinces. And some of the cost savings from permit trading in the linked cap-and-trade system might not be realized (Böhringer, Koschel, and Moslener 2008).

\section{Final Remarks}

A decentralized, interprovincial approach to carbon pricing would not lead to a single economy-wide carbon price and cost-effective emissions reductions in Canada in the foreseeable future. Federal action is needed. By introducing a national carbon price floor and a federal carbon tax to work alongside provincial carbon-

9 Of the five metrics they consider, Beugin et al. (2016) argue that adjusting explicit provincial carbon prices to take into account differences in emissions coverage and emission reductions achieved through international permit trading would be a comprehensive and relatively straightforward way to compare the stringency of provincial carbon-pricing policies. For example, according to their computations, the 2016 unadjusted carbon price differential between British Columbia and Quebec is about $\$ 13$ per tonne ( $\$ 30$ minus $\$ 17)$. The differential shrinks to about $\$ 7$ after adjusting for differences in permit trading and coverage.

10 Such measures have proven useful in the past to bring reluctant provinces on board with a federal or pan-Canadian initiative - for example, transitional grants to provinces that replaced their retail sales tax with the harmonized sales tax. 
pricing policies, the federal government could eliminate carbon-pricing differentials. And, by increasing the price floor over time, the federal government could improve Canada's prospects for achieving its 2030 emissionsreduction target.

A single carbon price and a level playing field also would create opportunities for more comprehensive carbon-pricing reform. Federal action might encourage provinces to adopt a common carbon-pricing instrument. Provinces might also agree to replace existing policies in favour of a federal carbon tax or a national cap-and-trade system. However they are achieved, a single Canada-wide carbon price and carbon-pricing instrument would facilitate the development of links to other systems, such as that of the European Union - links that are critical for reducing the global cost of addressing climate change. 


\section{References}

Aldy, J.E., W.A. Pizer, and K. Akimoto. 2015. “Comparing Emission Mitigation Efforts across Countries.” Discussion Paper 15-32. Washington, DC: Resources for the Future. June. Available online at http:// www.rff.org/research/publications/comparing-emissions-mitigation-efforts-across-countries.

Beugin, D., J. Dion, S. Elgie, N. Olewiler, and C. Ragan. 2016. "Comparing Stringency of Carbon Pricing Policies.” Montreal: Canada’s Ecofiscal Commission. July. Available online at http://ecofiscal.ca/ reports/comparing-stringency-carbon-pricing/.

Böhringer, C., E.J. Balistreri, and T.F. Rutherford. 2012. "The Role of Border Carbon Adjustment in Unilateral Climate Policy: Overview of an Energy Modeling Forum Study (EMF 29).” Energy Economics 34 (suppl. 2): S97-S110.

Böhringer, C., H. Koschel, and U. Moslener. 2008. "Efficiency Losses from Overlapping Regulation of EU Carbon Emissions.” Journal of Regulatory Economics 33 (3): 299-317.

Boothe, P., and F.-A. Boudreault. 2016. "By the Numbers: Canada's GHG Emissions." London, ON: Western University, Ivey School of Business, Lawrence National Centre for Policy and Development. Available online at http://www.ivey.uwo.ca/cmsmedia/2112500/4462-ghg-emissions-report-v03f.pdf.

Cameron, A., and T. McLeod. 2015. "Patchwork Pollution Solution: Stitching Together a Canadian Climate Plan." Calgary: Canada West Foundation, Centre for Natural Resources Policy. July. Available online at http://cwf.ca/research/publications/patchwork-pollution-solution-stitching-together-acanadian-climate-plan/.

Canada. 2016. Environment and Climate Change Canada. "National Inventory Report 1990-2014: Greenhouse Gas Sources and Sinks in Canada, Executive Summary.” Ottawa.

Courchene, T.J., and J.R. Allan. 2008. "The Provinces and Carbon Pricing: Three Inconvenient Truths.” Policy Options December 2008 - January 2009.

Flachsland, C., R. Marschinski, and O. Edenhofer. 2009. “To Link or Not to Link: Benefits and Disadvantages of Linking Cap-and-Trade Systems.” Climate Policy 9 (4): 358-72.

Haites, E., and M. Mehling. 2009. "Linking Existing and Proposed GHG Emissions Schemes in North America.” Climate Policy 9 (4): 373-88.

Haug, C., M. Frerk, and M. Santikarn. 2015. "Towards a Global Price on Carbon: Pathways for Linking Pricing Instruments.” Berlin: adelphi. Available online at https:/www.adelphi.de/en/system/files/ mediathek/bilder/towards_a_global_price_on_carbon_adelphi_2015.pdf.

Henry, D.D., N.Z. Muller, and R.O. Mendelsohn. 2011. "The Social Cost of Trading: Measuring the Increased Damages from Sulfur Dioxide Trading in the United States." Journal of Policy Analysis and Management 30 (3): 598-612.

Jaffe, J., and R. Stavins. 2007. "Linking Tradable Permit Systems for Greenhouse Gas Emissions Opportunities, Implications, and Challenges.” Report prepared for the International Emissions Trading Association. [Geneva]: IETA. Available online at http://belfercenter.ksg.harvard.edu/files/ IETA_Linking_Report.pdf. 
Keohane, N.O. 2006. "Cost Savings from Allowance Trading in the 1990 Clean Air Act: Estimates from a Choice-Based Model." In Moving to Markets in Environmental Regulation: Lessons from Twenty Years of Experience, C.E. Kolstad and J. Freeman (eds), 194-229. New York: Oxford University Press.

Metcalf, G., and D. Weisbach. 2012. "Linking Policies when Tastes Differ: Global Climate Policy in a Heterogeneous World.” Review of Environmental Economics and Policy 6 (1): 110-29.

Purdon, M., D. Houle, and E. Lachapelle. 2014. The Political Economy of California and Québec's Cap-andTrade Systems. Ottawa: University of Ottawa, Sustainable Prosperity.

Ranson, M., and R.N. Stavins. 2015. "Linkage of Greenhouse Gas Emissions Trading Systems: Learning from Experience.” Climate Policy 16 (3): 284-300.

Robins, A., P. Owusu, D. Munro, and L. Coad. 2016. A Changing Tide: British Columbia's Emerging Liquefied Natural Gas Industry. Ottawa: Conference Board of Canada.

Sartor, O., and N. Berghmans. 2011. "Carbon Price Flaw? The Impact of the UK's CO2 Price Support on the EU ETS.” Climate Brief 6. Paris: Institute for Climate Economics. Available online at http:// www.i4ce.org/download/climate-brief-n6-carbon-price-flaw-the-impact-of-the-uks-co2-pricesupport-on-the-eu-ets/.

Sawyer, D., and J. Peters. 2016. "Impact Modelling and Analysis of Ontario's Proposed Cap and Trade Program.” With Seton Stiebert and Noel Melton. Ottawa: EnviroEconomics. May 17. Available online at http://www.enviroeconomics.org/\#!Impact-Modelling-and-Analysis-ofOntario\%E2\%80\%99s-Proposed-Cap-and-Trade-Program/c1uze/573a64620cf23f57cc66dd05.

This E-Brief is a publication of the C.D. Howe Institute.

Tracy Snoddon is Associate Professor, Economics, and Associate Director, Viessmann European Research Centre, Lazaridis School of Business \& Economics.

This E-Brief is available at www.cdhowe.org.

Permission is granted to reprint this text if the content is not altered and proper attribution is provided. 